\title{
THE HIGH COURT ON CONSTITUTIONAL LAW: THE 2003 STATISTICS
}

\author{
ANDREW LYNCH* AND GEORGE WILLIAMS**
}

\section{INTRODUCTION}

The statistics set out below present information on the High Court's decisionmaking at both an institutional and individual level for 2003, with an emphasis on constitutional cases as a subset of the total. They have been compiled using a methodology developed by the Harvard Law Review for the United States Supreme Court and adapted for the High Court of Australia, ${ }^{1}$ which has previously been used to produce an empirical analysis of the first five years of the Gleeson Court. ${ }^{2}$ We do not outline that method again here. The only significant difference is that the data collection was done exclusively using the matters made available on the AustLII database for 2003. ${ }^{3}$

It is important to acknowledge at the outset the limitations which inhere in any empirical study over only one year. While the statistics capture what occurred in 2003, the reader should be wary of making broad generalisations about the behaviour of the Court and its justices. For example, where percentage calculations have been given in addition to raw figures these should obviously be treated more warily than those produced after a significantly longer study. Caution is also warranted in the case of Justices Gaudron and Heydon, neither of whom served a full year on the Court in $2003 .^{4}$

With this caveat, the regular presentation of empirical data on the decision making of the High Court is a valuable means of enhancing understanding of the

* Senior Lecturer, Faculty of Law, University of Technology, Sydney.

* Anthony Mason Professor and Director, Gilbert + Tobin Centre of Public Law, Faculty of Law, University of New South Wales; Barrister, New South Wales Bar. We thank Ben Golder for his research assistance. These statistics were originally delivered at the Gilbert + Tobin Centre of Public Law, 2004 Constitutional Law Conference, Sydney, 20 February 2004.

1. Andrew Lynch, 'Dissent: Towards a Methodology for Measuring Judicial Disagreement in the High Court of Australia' (2002) 24 Sydney Law Review 470.

2 Andrew Lynch, 'The Gleeson Court on Constitutional Law: An Empirical Analysis of its First Five Years' (2003) 26 University of New South Wales Law Journal 32.

3 See Australian Legal Information Institute <http://www austlii.edu.aw/au/cases/cth/HCA/2003/> at 9 July 2004.

4 Justice Gaudron retired from the Court on 10 February 2003 and Heydon J was appointed to the Court on the next day. 
Court's work..$^{5}$ The reader may simply consider the figures presented here as a stand-alone snapshot of the High Court's constitutional work in 2003, or can look for the continuation of trends and patterns through comparison with earlier statistical findings. Either way, the tables are one way of appreciating the Court's performance and so 'are not an end in themselves but are intended to present a foundation for more detailed consideration.' ${ }^{6}$ Some explanation of the tables is provided, purely for the purpose of clarification rather than as an attempt at substantive or qualitative analysis. That we leave to those engaged in commenting on the High Court's performance: who will hopefully find material of interest and utility in what is presented here.

\section{STATISTICS}

TABLE A - HIGH COURT OF AUSTRALIA CASES REPORTED FOR PERIOD

\begin{tabular}{|c|c|c|}
\hline & $\begin{array}{c}\text { All Cases Reported } \\
\text { for Period }\end{array}$ & $\begin{array}{c}\text { All Constitutional Cases } \\
\text { Reported for Period }\end{array}$ \\
\hline Unanimous & 10 & 3 \\
By & $(13.70 \%)$ & $(18.75 \%)$ \\
\hline Concurrence & 26 & 7 \\
\hline $\begin{array}{c}\text { Majority over } \\
\text { Dissent }\end{array}$ & $(35.62 \%)$ & $(43.75 \%)$ \\
\hline TOTAL & $(50.68 \%)$ & 6 \\
& 73 & $(37.50 \%)$ \\
\hline
\end{tabular}

The data collection for Table A was done exclusively using the 75 matters made available on AustLII in its 2003 database for the High Court. Three singlejudge decisions of the High Court were not included in tallying for the purposes of this study. One case report, ${ }^{7}$ which contains three individual matters, was tallied twice due to the differentiation drawn by the members of the Court in their judgments. $^{8}$

5 The obvious example of this is the annual presentation of statistics for each term of the United States Supreme Court that can be found in the pages of the Harvard Law Review. However, less well-known studies exist and may have a much smaller range of data in one year than either the United States Supreme Court or the High Court of Australia: see for example, the annual statistics given for the South African Constitutional Court in the South African Journal on Human Rights since 1995.

6 'The Supreme Court, 1948 Term' (1949) 63 Harvard Law' Review $119,119$.

7 New South Wales v Lepore: Samin v Queensland: Rich v Queensland [2003] HCA 4; (2003) 195 ALR 412 .

8 For a detailed explanation of the purpose behind multiple tallying of some cases, see Lynch, above $\mathrm{n} 1$, $500-2$. 
From this table it can be seen that a total of 73 matters are reported for 2003 , with 16 , or close to 22 per cent, being constitutional in character. This classification is made generously using the presence of constitutional descriptors or provisions in the catchwords accompanying the judgments. ${ }^{9}$ Admittedly, the degree to which constitutional questions were central to the resolution of these cases varied. We direct the reader to Justice Sackville's qualitative appraisal of these matters, in which he states that in 2003 nine cases decided were of 'substantial constitutional importance'. ${ }^{10}$ Of these, five were of 'general importance' whilst the remaining four were of 'more limited significance." 11 We agree with his assessment of these cases and that the 'other cases decided in 2003 raised less substantial constitutional issues' (of which we have identified seven). Nonetheless, the employment of this more inclusive criteria to characterise a case as 'constitutional' has the advantage of being objective, transparent and replicable by other scholars.

Table A also indicates that disagreement in its most tangible form - opinions dissenting from the final orders reached by a majority of the Court - was less prevalent in constitutional matters ( 37.50 per cent) than in the cases taken as a whole ( 50.68 per cent). In fact, if one is to compare these figures with those which were presented for the five years preceding, 12 the percentage of constitutional cases carrying a dissenting opinion was markedly less in 2003 than in any previous full year of the Gleeson Court, while the percentage of cases overall with minority judgments remained steady.

9 While this is a reliable method in respect of the great majority of cases, the quirks of individual editors can play a part. To take an example from an earlier year than that under review, the case of Wong $v$ The Queen is reported at (2001) 207 CLR 584 as simply a criminal law matter, despite constitutional arguments receiving some judicial attention. By contrast, in the report of the case at (2001) 185 ALR 233, the catchwords do indicate the constitutional aspects of the case. Researchers using different report series or databases may, as a consequence, produce slightly different figures as a result.

10 Justice Ronald Sackville, 'The 2003 Term: The Inaccessible Constitution' (2004) 27 University of New South Wales Law Journal 66, 83.

II Ibid.

12 Lynch, above n 2, 42-3. 
TABLE B - CONSTITUTIONAL CASES - HOW RESOLVED ${ }^{13}$

\begin{tabular}{|c|c|c|c|}
\hline Size of Bench & Number of Cases & How Resolved & Frequency \\
\hline \multirow{5}{*}{7} & \multirow{5}{*}{$\begin{array}{c}5 \\
(31.25 \%)\end{array}$} & Unanimous & $1(6.25 \%)$ \\
\hline & & By concurrence & $3(18.75 \%)$ \\
\hline & & $6: 1$ & 0 \\
\hline & & $5: 2$ & 0 \\
\hline & & $4: 3$ & $1(6.25 \%)$ \\
\hline \multirow{6}{*}{6} & \multirow{6}{*}{$(37.50 \%)$} & & 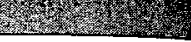 \\
\hline & & Unanimous & 0 \\
\hline & & By concurrence & $4(25.00 \%)$ \\
\hline & & $5: 1$ & $2(12.50 \%)$ \\
\hline & & $4: 2$ & 0 \\
\hline & & $3: 3$ & 0 \\
\hline \multirow{4}{*}{5} & \multirow[b]{4}{*}{$(18.75 \%)$} & Unanimous & 0 \\
\hline & & By concurrence & 0 \\
\hline & & $4: 1$ & $3(18.75 \%)$ \\
\hline & & $3: 2$ & 0 \\
\hline & \multirow[b]{5}{*}{$(12.50 \%)$} & & 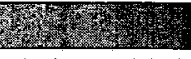 \\
\hline \multirow{4}{*}{3} & & Unanimous & $2(12.50 \%)$ \\
\hline & & By concurrence & 0 \\
\hline & & & \\
\hline & & $2: 1$ & 0 \\
\hline
\end{tabular}

Table B provides further detail as to how the 16 constitutional cases were resolved by the Court as comprised of a varying number of justices. The prevalence of matters in which only six judges presided over a bench comprised of all seven justices is explained by the time-lag incurred whenever a new justice joins the bench. ${ }^{14}$ As shall be seen from subsequent tables, Justice Heydon's presence on the bench has yet to fully manifest itself in the opinions of the Court.

13 All percentages given in this table are of the total number of constitutional cases (16).

14 For the curious, the two constitutional cases determined by a bench of three members were Glennan $y$ Commissioner of Taxation [2003] HCA 31; (2003) 198 ALR 250 and Re Carmody; Ex parte Glennan [2003] HCA 32; (2003) 198 ALR 259, in which s 75(v) of the Constitution was, to a degree, the object of interpretation. 
TABLE C - SUBJECT MATTER OF CONSTITUTIONAL CASE REPORTS

\begin{tabular}{|l|c|l|}
\hline \multicolumn{1}{|c|}{ Topic } & $\begin{array}{c}\text { No. of Case } \\
\text { Reports }\end{array}$ & \multicolumn{1}{|c|}{$\begin{array}{c}\text { References to Case Reports } \\
\text { (Italics indicate repetition) }\end{array}$} \\
\hline Clause 5 & 2 & 31,47 \\
\hline s 51(i) & 1 & 43 \\
\hline s 51(ii) & 1 & 3 \\
\hline s 51(xix) & 1 & 2,72 \\
\hline s 51(xxvii) & 2 & 2,72 \\
\hline s 51(xxix) & 1 & 67 \\
\hline s 51(xxxvii) & 1 & 2 \\
\hline s 51(xxxix) & 2 & 65,66 \\
\hline s 52(i) & 1 & 3 \\
\hline s 55 & 1 & 73 \\
\hline s 75(iii) & 6 & $2,30,31,32,56,60$ \\
\hline s 75(v) & 1 & 47 \\
\hline s 76 & 1 & 47 \\
\hline s 77(iii) & 1 & 47 \\
\hline s 78 & 2 & 19,20 \\
\hline s 80 & 1 & 47 \\
\hline s 90 & 1 & 67 \\
\hline s 106 & 1 & 67 \\
\hline s 107 & 1 & 3 \\
\hline s 114 & 1 & 72 \\
\hline s 117 & 1 & 67 \\
\hline s 128 & & \\
\hline
\end{tabular}

Table $\mathrm{C}$ lists the provisions of the Constitution that arose for consideration in the 16 matters tallied. The table reveals that a large number of the cases dealt with issues of judicial power and judicial review. The figures also reflect a change in the workload of the Court. The tables of judicial workload annexed to the High Court's 2002-03 Annual Report show a 217 per cent increase in the number of matters filed by comparison with the previous year. This striking increase is reflected most dramatically in the Court's original jurisdiction, where the number of constitutional writs filed increased from 300 to 2131 in 2002-03. Of those applications, 2105 (or 99 per cent) involved migration matters. Migration matters made up 82 per cent of all matters filed in the past year. ${ }^{16}$

I5 The reference numbers given are simply a shorthand citation of the case - the medium-neutral citation for each of these cases simply requires prefixing the number given with '[2003] HCA'.

16 High Court of Australia, Annual Report 2002-2003 (2003) $8<\mathrm{http}: / /$ www.hcourt.gov.au/annual_reports/ 2003annual.pdf $>$ at 9 July 2004 
TABLE D(I) - ACTIONS OF INDIVIDUAL JUSTICES: ALL CASES

\begin{tabular}{|c|c|c|c|c|}
\hline & $\begin{array}{c}\text { Number of } \\
\text { Judgments }\end{array}$ & $\begin{array}{c}\text { Participation in } \\
\text { Unanimous } \\
\text { Judgment }\end{array}$ & Concurrences & Dissents \\
\hline $\begin{array}{c}\text { Gleeson } \\
\text { CJ }\end{array}$ & 61 & $3(4.92 \%)$ & $53(86.89 \%)$ & $5(8.20 \%)$ \\
\hline Gaudron J & 6 & 0 & $5(83.33 \%)$ & $1(16.67 \%)$ \\
\hline McHugh J & 57 & $7(12.28 \%)$ & $43(75.44 \%)$ & $7(12.28 \%)$ \\
\hline $\begin{array}{c}\text { Gummow } \\
\text { J }\end{array}$ & 65 & $9(13.85 \%)$ & $54(83.08 \%)$ & $2(3.08 \%)$ \\
\hline Kirby J & 65 & $7(10.78 \%)$ & $33(50.77 \%)$ & $25(38.46 \%)$ \\
\hline Hayne J & 59 & $8(13.56 \%)$ & $47(79.66 \%)$ & $4(6.78 \%)$ \\
\hline Callinan J & 61 & $6(9.84 \%)$ & $46(75.41 \%)$ & $9(14.75 \%)$ \\
\hline Heydon J & 28 & $3(10.71 \%)$ & $23(82.14 \%)$ & $2(7.14 \%)$ \\
\hline
\end{tabular}

While observers of the High Court may have an accurate, although impressionistic reading of the behaviour of the Court as a whole, it is often more intriguing to see the patterns of the individual justices themselves - something that is not always easy to appreciate, except with hindsight. Table $\mathrm{D}(\mathrm{I})$ presents how the judges each handled the work which faced them in 2003. The presence of Gaudron $\mathbf{J}$ is included for the sake of completeness and little store should be given to the percentage results for her Honour, which bear no comparison with those of her colleagues who served out the full year. In interpreting the results, it should also be borne in mind that Heydon $J$ sat on a little less than half of the matters in which the other justices sat.

For the remaining six justices, the following few features stand out. Chief Justice Gleeson has joined a noticeably lower proportion of unanimous opinions in comparison with the rest of the Court, while the other five justices apparently had greater opportunity to sit on cases in circumstances which were amenable to the securing of unanimity. Justice Gummow, more often than any other justice found himself on a bench speaking with one voice. ${ }^{17}$ The Chief Justice's limited involvement in unanimous opinions should not, however, overshadow his very

17 His Honour is assisted in this respect by being one of the three justices sitting on the two unamimous constitutional cases discussed in respect of Table B. We would stress that a variety of factors must go towards aiding or abetting the occurrence of unanimity including, obviously, who is sitting with whom and the nature of the matter before the bench. The Chief Justice's lower rate in comparison with his Honour's colleagues does not necessarily pertain to his personal judicial style. Indeed his Honour's high level of concurrence generally would tend to suggest that he is not personally an obstacle to unanimity. 
high rate (the highest) of opinions that concurred in the opinion of the Court. This may be contrasted with the proportion of concurrences for Kirby J. Although, his Honour was involved in more unanimous judgments than the Chief Justice, his rate of agreement with the other justices is otherwise by far the lowest - just over 50 per cent of cases on which he sat. On all other occasions, Kirby J maintained his position as an outsider on the Court with a dissent rate of over 38 per cent for 2003, which is higher than his total dissent percentage for the preceding five years ( 34 per cent). ${ }^{18}$ In fact, the place of these six judges along the spectrum of dissent has not altered in order in 2003 when compared with the last five years. The justice least likely to find himself disagreeing with a majority of his colleagues is Gummow $\mathrm{J}$, followed by Hayne $\mathrm{J}$, Gleeson $\mathrm{CJ}$, justices McHugh and Callinan, and then, by some distance, Kirby J. Individually, they may have dissented a little more or a little less as a percentage of their caseload than in the preceding years, but that order remains the same.

TABLE D(II) - ACTIONS OF INDIVIDUAL JUSTICES: CONSTITUTIONAL CASES

\begin{tabular}{|l|c|c|c|c|}
\hline & $\begin{array}{c}\text { Number of } \\
\text { Judgments }\end{array}$ & $\begin{array}{c}\text { Participation } \\
\text { in Unanimous } \\
\text { Judgment }\end{array}$ & Concurrences & Dissents \\
\hline Gleeson CJ & 14 & $1(7.14 \%)$ & $13(92.86 \%)$ & 0 \\
\hline Gaudron J & 2 & 0 & $2(100 \%)$ & 0 \\
\hline McHugh J & 11 & $1(9.09 \%)$ & $9(81.82 \%)$ & $1(9.09 \%)$ \\
\hline Gummow J & 16 & $3(18.75 \%)$ & $13(81.25 \%)$ & 0 \\
\hline Kirby J & 14 & $1(7.14 \%)$ & $7(50 \%)$ & $6(42.86 \%)$ \\
\hline Hayne J & 13 & $3(23.08 \%)$ & $10(76.92 \%)$ & 0 \\
\hline Callinan J & 14 & $3(21.43 \%)$ & $10(71.43 \%)$ & $1(7.14 \%)$ \\
\hline Heydon J & 8 & $1(12.5 \%)$ & $7(87.5 \%)$ & 0 \\
\hline
\end{tabular}

18 Lynch, above $\mathrm{n} 2,47$. 
Table $\mathrm{D}$ (II) records the actions of the justices in the constitutional cases of 2003. Even allowing for the small sample size, there are one or two things of note. A caveat should be applied in respect of the statistics given for unanimous judgments - the results for Gummow, Hayne and Callinan $\mathrm{JJ}$ are inflated by their Honours' constituting a three-bench court for two matters in which discussion of s 75(v) of the Constitution took place. The third case in which unanimity occurred - and on which all the justices sat - was the relatively straightforward matter of Re Maritime Union of Australia; Ex parte CSL Pacific Inc, ${ }^{19}$ that concerned s 51(i) of the Constitution.

It is the dissents - or rather the lack thereof - that is most striking about this Table and which can be appreciated without any qualification. In the five years prior to 2003, Gummow J dissented in only one constitutional case and that still stands. ${ }^{20}$ Chief Justice Gleeson and Hayne $\mathrm{J}$ have also maintained their very low record for minority opinions by not filing a constitutional dissent in 2003.21 Justices McHugh and Callinan only dissented on one occasion each: the decision of Shaw v Minister for Immigration and Multicultural Affairs ('Shaw'). ${ }^{22}$ Thus, setting to one side Kirby J's position of disagreement in almost every second constitutional case - the two most significant being Shaw and Attorney-General (WA ) Marquet $^{23}$ - there seemed a remarkable level of consensus across the rest of the Court than in previous years.

This, of course, is to consider only disagreement in its most explicit form. It cannot be denied that within the various concurring judgments of the Court's members there exists ample evidence of divergent reasoning. However, these subtleties of difference within concurrences do not readily lend themselves to quantitative representation.

19 (2003) 200 ALR 39.

20 Lynch, above $\mathrm{n} 2,50$

21 The Chief Justice and Hayne $\mathrm{J}$ have only filed dissents in, respectively, two and four constitutional matters to date.

22 (2003) 211 CLR 476

23 (2003) 202 ALR 143 
TABLE E(I) - JOINT JUDGMENT AUTHORSHIP: ALL CASES

\begin{tabular}{|c|c|c|c|c|c|c|c|c|}
\hline 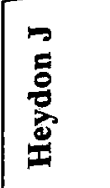 & $=\frac{\bar{o}}{\frac{0}{d}}$ & $\stackrel{\pi}{z}$ & 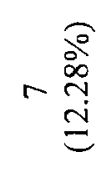 & $=\frac{\stackrel{0}{\circ}}{\stackrel{0}{0}}$ & 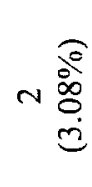 & 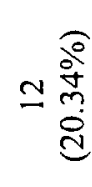 & $\infty \stackrel{\frac{\partial}{D}}{=}$ & \\
\hline 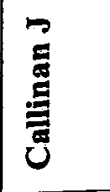 & 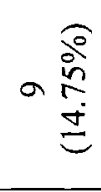 & 0 & 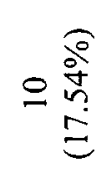 & $=\underset{\stackrel{8}{0}}{\stackrel{d}{d}}$ & $n$ n & $=\stackrel{0}{\stackrel{\circ}{\circ}}$ & & 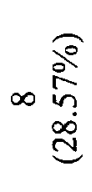 \\
\hline 离 & 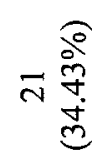 & $m \stackrel{a}{0}$ & 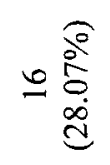 & 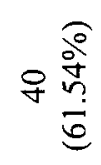 & 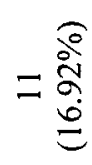 & & $=\frac{\widehat{o}}{\frac{\partial}{d}}$ & 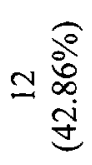 \\
\hline 家 & 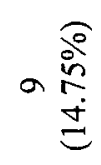 & N & 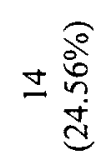 & m $\stackrel{0}{\stackrel{d}{0}}$ & & 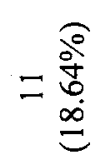 & 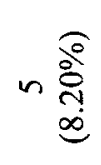 & 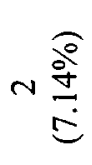 \\
\hline D & ১্ণ & 命 & 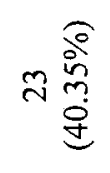 & & m & o & 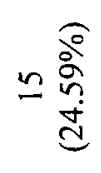 & $=\frac{\frac{0}{8}}{\frac{8}{8}}$ \\
\hline 总 & 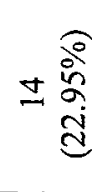 & 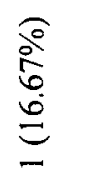 & | & 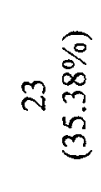 & $\pm \frac{\widehat{o}}{\frac{o}{v}}$ & $-\frac{\widehat{\beth}}{\stackrel{\overbrace{}}{d}}$ & ○ & - - \\
\hline 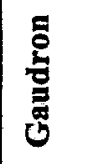 & 0 & & $-\stackrel{\stackrel{o}{\circ}}{\stackrel{i}{i}}$ & 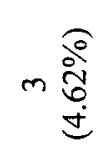 & $\sim \stackrel{\triangle}{\circ}$ & 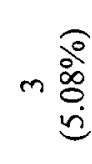 & 0 & $\stackrel{\Xi}{z}$ \\
\hline \multirow[t]{2}{*}{$\begin{array}{l}\text { 离 } \\
\frac{\mathbb{E}}{\zeta}\end{array}$} & & 0 & 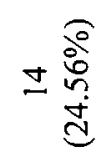 & স & $\begin{array}{r}\widehat{0} \\
0 \stackrel{0}{0} \\
\text { a }\end{array}$ & 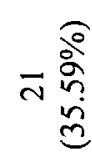 & 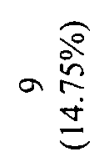 & 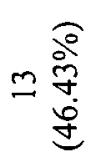 \\
\hline & 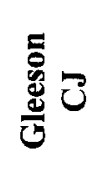 & ح & 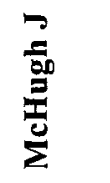 & D & 苞 & 总 & 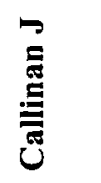 & 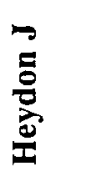 \\
\hline
\end{tabular}




\begin{tabular}{|c|c|c|c|c|c|c|c|c|}
\hline & $\begin{array}{l}\text { Gleeson } \\
\text { CJ }\end{array}$ & Gaudron & McHugh J & $\underset{\mathbf{J}}{\text { Gummow }}$ & Kirby J & Hayne J & Callinan $\mathbf{J}$ & $\begin{array}{c}\text { Heydon } \\
\text { J }\end{array}$ \\
\hline $\begin{array}{l}\text { Gleeson } \\
\mathbf{C J}\end{array}$ & 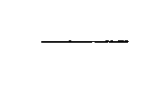 & 0 & $\begin{array}{c}3 \\
(21.43 \%)\end{array}$ & $\begin{array}{c}9 \\
(64.29 \%)\end{array}$ & $3(21.43 \%)$ & $\begin{array}{c}8 \\
(57.14 \%)\end{array}$ & $3(21.43 \%)$ & $\begin{array}{c}6 \\
(42.86 \%)\end{array}$ \\
\hline $\begin{array}{c}\text { Gaudron } \\
\quad \mathbf{J}\end{array}$ & 0 & 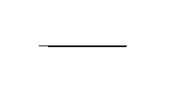 & $\begin{array}{c}1 \\
(50 \%)\end{array}$ & $\begin{array}{c}2 \\
(100 \%)\end{array}$ & $\begin{array}{c}1 \\
(50 \%)\end{array}$ & $2(100 \%)$ & 0 & $\mathrm{n} / \mathrm{a}$ \\
\hline McHugh J & $\begin{array}{c}3 \\
(27.27 \%)\end{array}$ & $\begin{array}{c}1 \\
(9.09 \%)\end{array}$ & $\ldots$ & $\begin{array}{c}6 \\
(54.55 \%)\end{array}$ & $4(36.36 \%)$ & $\begin{array}{c}5 \\
(45.45 \%)\end{array}$ & $1(9.09 \%)$ & $\begin{array}{c}1 \\
(9.09 \%)\end{array}$ \\
\hline$\underset{\mathbf{J}}{\text { Gummow }}$ & $\begin{array}{c}9 \\
(56.25 \%)\end{array}$ & $\begin{array}{c}2 \\
(12.50 \%)\end{array}$ & $\begin{array}{c}6 \\
(37.5 \%)\end{array}$ & 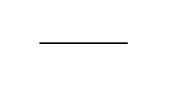 & $\begin{array}{c}4 \\
(25 \%)\end{array}$ & $\begin{array}{c}13 \\
(81.25 \%)\end{array}$ & $5(31.25 \%)$ & $\begin{array}{c}7 \\
(43.75 \%)\end{array}$ \\
\hline Kirby J & $\begin{array}{c}3 \\
(21.43 \%)\end{array}$ & $\begin{array}{c}1 \\
(7.14 \%)\end{array}$ & $\begin{array}{c}4 \\
(28.57 \%)\end{array}$ & $\begin{array}{c}4 \\
(28.57 \%)\end{array}$ & - & $\begin{array}{c}4 \\
(28.57 \%)\end{array}$ & $1(7.14 \%)$ & $\begin{array}{c}1 \\
(7.14 \%)\end{array}$ \\
\hline Hayne J & $\begin{array}{c}8 \\
(61.54 \%)\end{array}$ & $\begin{array}{c}2 \\
(15.38 \%)\end{array}$ & $\begin{array}{c}5 \\
(38.46 \%)\end{array}$ & $\begin{array}{c}13 \\
(100 \%)\end{array}$ & $4(30.77 \%)$ & . & $5(38.46 \%)$ & $\begin{array}{c}5 \\
(38.46 \%)\end{array}$ \\
\hline Callinan $\mathbf{J}$ & $\begin{array}{c}3 \\
(21.43 \%)\end{array}$ & 0 & $\begin{array}{c}1 \\
(7.14 \%)\end{array}$ & $\begin{array}{c}5 \\
(35.71 \%)\end{array}$ & $1(7.14 \%)$ & $\begin{array}{c}5 \\
(35.71 \%)\end{array}$ & 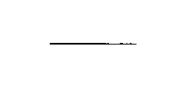 & $\begin{array}{c}3 \\
(21.43 \%)\end{array}$ \\
\hline Heydon J & $\begin{array}{c}6 \\
(75 \%)\end{array}$ & $\mathrm{n} / \mathrm{a}$ & $\begin{array}{c}1 \\
(12.50 \%)\end{array}$ & $\begin{array}{c}7 \\
(87.50 \%)\end{array}$ & $1(12.50 \%)$ & $\begin{array}{c}5 \\
(62.50 \%)\end{array}$ & $3(37.50 \%)$ & 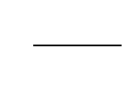 \\
\hline
\end{tabular}


Tables $\mathrm{E}(\mathrm{I})$ and $\mathrm{E}(\mathrm{II})$ indicate the number of times a particular justice jointly authored an opinion with his or her colleagues. The most notable aspect of these tables is the continuation of Justice Gummow's attractiveness as a co-author for all justices on the Court. ${ }^{24}$ With the exception of Kirby $\mathrm{J}$ writing marginally more of his total opinions with McHugh $\mathrm{J}$, Gummow $\mathrm{J}$ is the justice over all others who was most involved in joint opinions with each of his colleagues. This pattern translates to the constitutional case table (Table E(II)). In all thirteen of the constitutional matters he sat on in 2003, Hayne J delivered his opinion in concert with Gummow $\mathrm{J}$ - a level of co-operation which no other two judges can match (again, we can disregard Gaudron J). Even so, Gummow J was still every other justice's preferred co-author in constitutional matters or was at least tied with another justice in this position (Kirby $\mathrm{J}$ joined just as often with McHugh $\mathrm{J}$ or Hayne J; Callinan J joined Hayne J as often as he did Gummow J).

\section{CONCLUSION}

Doubtless, the reader may find specific features of interest in this material. Even when taken as a single year on its own, there are patterns of note. Our aim in presenting this material is to record what occurred amongst the justices of the High Court in determining the cases of 2003. This should make future developments and shifts in the Court's work simpler to recognise and perhaps easier to understand and analyse.

24 This need not necessarily equate to the level of influence which Gummow J personally enjoys on the Court. In saying that Gummow J has the highest level of concurrence and is the most preferred co-author of other justices, we are simply recording those facts. It is a mistake to simply assume that Gummow J therefore is the Court's intellectual leader. Apart from the fact that in any case the statistics show that he is very closely matched by those around him, it might be just as true to say that he simply best represents the common ground which exists between the other justices. We offer no opinion here as to which of those explanations we think is supported by these statistics. 


\section{APPENDIX - EXPLANATORY NOTES}

The purpose of the notes contained in this appendix is to identify when and how discretion has been exercised by the researcher in compiling the statistical tables discussed throughout this paper. As the editors of the Harvard Law Review have stated, when explaining their own methodology, "the nature of the errors likely to be committed in constructing the tables should be indicated so that the reader might assess for himself the accuracy and value of the information conveyed'.25

\section{A Method employed in tallying multiple matter case reports}

The following report was tallied multiple times due to distinctions being drawn between the matters in the judgments and orders made: New South Wales $v$ Lepore; Samin v Queensland; Rich v Queensland [2003] HCA 4. ${ }^{26}$ The report contains three individual matters. Jurisdictional differences led to sufficient differentiation being drawn by the members of the Court in their judgments between the two Queensland matters on one hand and Lepore on the other. The case was tallied as two matters. ${ }^{27}$

\section{B Decisions to tally dissents warranting explanation}

\section{$1 \quad[2003] \mathrm{HCA} 4(i)^{28}$}

Justice Callinan is tallied as dissenting because he would allow the appeal in whole and enter judgment for the appellant, whereas the order of the Court is to allow it in part and remit.

\section{2 [2003] HCA $34^{29}$}

Justice Hayne is tallied as dissenting because although he allows the appeal, his order is to set aside only paragraph 2 of the NSW Court of Appeal's orders, whereas the order of the Court is to set aside paragraphs 1,2 and 3 .

\footnotetext{
'The Supreme Court, 1967 Term' (1968) 82 Harvard Law Review 63, 301. (2003) 195 ALR 412

The purpose behind multiple tallying in such circumstances - and the competing arguments - are considered at length by Lynch, above n 1, 500-2. Separate tallying allows disagreement amongst the bench to be isolated to one specific matter, rather than having it magnified in instances where there is actually a great deal of consensus. Of course, there are drawbacks to such an approach as well. However, while multiple tallying inflates raw data, the distorting effect is minimised through greater reliance upon the percentage figures. And once again, identifying which cases have involved discretion on the part of the researcher is vital in the interests of a transparent methodology. The choice to use a multiple tally should be noted and justified - hence the inclusion of this table here - the sentiment from the Harvard Law Review accompanying $\mathrm{n} 25$ is the guiding principle.

28 (2003) 195 ALR 412.

29 (2003) 198 ALR 137
} 
The University of New South Wales Law Journal is a refereed journal which publishes three issues per year: two General Issues, containing articles, comments and case notes on a broad range of topics selected from among those submitted to the Law Journal, and a Thematic Issue, devoted to a single topic of current legal interest. In addition, the Law Journal publishes two editions of Forum, each addressing a controversial legal issue through a series of concise articles. Forum is also reprinted in the next General Issue of that year.

\section{Submissions}

The Law Journal welcomes original contributions on any topic of legal interest for inclusion in its General Issues. (Contributions to the Thematic Issue and to Forum are at the invitation of the Editors.) The Law Joumal does not accept contributions that have either been published previously or submitted for publication elsewhere.

Submissions should be addressed to the Editors, and will be accepted in either hard copy or by electronic mail. If submitted in hard copy, an electronic version on a three-and-ahalf inch disk must also be included. Electronic copies must be in Microsoft Word format, preferably Word 97 or later. Please consult the Law Journal's website for submission dates, publication policy and style guide:

$<$ http://unswlawjournal.unsw.edu.au $>$.

\section{Subscriptions}

A subscription to the Law Journal costs A $\$ 110$ per year (including GST), and includes two General Issues, one Thematic Issue and two editions of Forum. Back issues and individual copies of General and Thematic Issues may also be purchased at a cost of A $\$ 38.50$ each, and copies of Forum at A $\$ 15$ (both prices include GST). Note that these prices are subject to change without notice. Postage and handling fees apply to all individual sales.

All correspondence regarding subscriptions, back issues and general queries should be addressed to:

The Executive Editor

The University of New South Wales Law Journal

Faculty of Law

The University of New South Wales

Sydney NSW 2052

Australia

Telephone: $\quad+61293852237$

Facsimile: $\quad+61293851175$

Email: law.journal@unsw.edu.au

For North American subscriptions please contact:

Gaunt Inc

3011 Gulf Drive

Telephone:

9417785211

Holmes Beach

Facsimile:

9417785252

Florida 34217-2199 USA

Email: info@gaunt.com 
This issue may be cited as (2003) 26(1) UNSWLJ.

(c) The University of New South Wales Law Journal and contributors, 2003.

ISSN 0313-0096.

The Dewey Decimal Number of this volume is 347.05 UNSWLJ.

Cover typeset by Nicole Cisterne.

Printed by Ligare Pty Limited.

Articles in this issue will also be available on the Internet via the Australasian Legal Information Institute <http://www.austlii.edu.au> and the Law Journal's website $<$ http://www.unswlawjournal.unsw.edu.au>. 